\title{
Quality Characteristics of Ginseng Coffee Treated by Coating of White Ginseng Extract
}

\author{
Kyung-Tack Kim*, Young-Chul Lee, Chang-Won Cho, YoungKyoung Rhee and Hye-Min Bae \\ Regional Food Industry Research Group, Korea Food Research Institute, Sungnam 463-746, Korea \\ (Received November 20, 2009; Revised January 18, 2010; Accepted January 19, 2010)
}

\begin{abstract}
The quality attributes of coffee treated with different concentrations of white ginseng extract were examined. Increased concentration of white ginseng extract was associated with higher color values (Hunter L. a, b scale). The crude saponin contents of untreated roasted coffee beans (control) and those coated with $5^{\circ}$ Brix (WGC-1) and $20^{\circ}$ Brix white ginseng extract (WGC-2) were $8.29 \%, 8.74 \%$, and $8.93 \%$, respectively. The total ginsenoside contents of WGC-1 and WGC-2 were $0.3 \mathrm{mg} / \mathrm{g}$ and $0.6 \mathrm{mg} / \mathrm{g}$, respectively. In the case of major ginsenosides, the contents of ginsenosides $\mathrm{Rg}_{1}$, $\mathrm{Rg}_{2}, \mathrm{Rb}_{1}, \mathrm{Rb}_{2}, \mathrm{Rg}_{2}, \mathrm{Rh}_{1}$, and $\mathrm{Rg}_{3}$ increased directly with the concentration of white ginseng extract. Total sugar and acidic polysaccharide contents also increased directly with the concentration of white ginseng extract. The coffee beans coated with ginseng extract scored significantly higher ginseng taste scores than the control $(\mathrm{p}<0.005)$ in sensory evaluation. In terms of coffee taste, WGC-2 had significantly lower scores than the commercial coffee bean. In the consumer sensory evaluation, overall preference did not differ significantly among the treatments.
\end{abstract}

Key words : ginseng coffee, white ginseng extract, coffee bean, ginsenoside, sensory evaluation

\section{INTRODUCTION}

Belonging to Araliaceae, ginseng (Panax ginseng C.A Meyer) is a perennial herb that has long been used as an herbal medicine for maintenance and improvement of human health [1]. Ginseng's main active compound is ginseng saponin, also known as ginsenoside. Ginsenoside has a very distinct chemical structure compared to saponins found in other plants. The chemical structure of ginsenoside has been elucidated by Shibata et al. [2]. Ginsenoside has been shown to possess anti-diabetic activity [3], antitumor effects [4], and antioxidant activity [5], to prevent arteriosclerosis and hypertension [6, 7] and improve liver function [8], to have anti-fatigue and anti-stress activity $[9,10]$ as well as anti-inflammatory effects [11] and to improve allergic conditions and protein synthesis activity $[12,13]$. Ginseng is grown for 4 6 years and harvested from August to October. Freshly harvested ginseng accounts for much of the market. The primary processed products are categorized as either red ginseng or white ginseng products depending on the method of production. Secondary processed products derived from primary pro-

* Corresponding author. E-mail: tack@kfri.re.kr Phone: +82-31-780-9096, Fax: +82-31-709-9876 cessed products are again classified into either red ginseng or white ginseng products [14]. Market data of ginseng consumption in Korea from 2001 to 2005 suggest that fresh ginseng accounted for $50 \%$ of consumption, followed by white ginseng at $33 \%$, red ginseng at $15 \%$, and Taegeuk ginseng (semi-red ginseng, Yin-Yang ginseng) at $2 \%$. Interestingly, consumption of white ginseng products such as ginseng extract and ginseng tea have been steadily decreasing since 1996, while the production and consumption of red ginseng products such as red ginseng extracts, red ginseng tea, and red ginseng capsules have all increased. With accumulating scientific evidence of the many beneficial effects of ginseng (Panax ginseng) and the introduction of ginseng as a raw material for making functional food, global demand for ginseng has risen dramatically. The main areas of ginseng production are China, parts of North America, Chile, Australia, and New Zealand. In China, ginseng production increased from 1,600 tons in 1985 to 8,000 tons in 1995 , a five-fold increase within a decade [15]. Conversely, ginseng production in Korea has been decreasing, and the market share of Korean ginseng is uncertain under controls by the World Trade Organization. Under these difficulties, solutions to increase the production and sale of Korean ginseng are needed, as is research to develop high-quality 
Korean ginseng products as functional foods or medicines distinct from those produced in other countries [16, 17]. In addition, Korea ranks eleventh in the world in terms of coffee consumption (300 cups of coffee per person in a year), and thus the Korean coffee industry must keep pace with demand. The Korean coffee industry imports and processes approximately 80,000 tons of coffee beans every year, worth approximately 1 billion Korean won, and exports coffee products worth approximately 60 million U.S. dollars. It is expected that within a few years, the profits from coffee exports will exceed the cost of importing coffee beans. Contemporary coffee products increase the consumer's well-being, and various products such as coffee latte and green tea latte are on the market to suit many different consumer tastes. Currently, ginseng coffees consist of coffee mixed with ginseng powder. Considering the present market trend toward sophisticated coffee tastes with emphasis on high quality and functionality, this study examined the quality attributes of ginseng coffee created by combining coffee beans with white ginseng extracts and hydroxypropyl methyl cellulose (HPMC), by a microspraying and coating process.

\section{MATERIALS AND METHODS}

\section{Materials}

Samples were prepared from Columbia Excelso coffee beans purchased from Coffee Nouri Co.(Seoul, Korea), white ginseng extract purchased from Guan Industry Co. (Seoul, Korea), and HPMC purchased from Samsung Chemical Co. (Seoul, Korea).

\section{Coating with white ginseng extract and production} of ginseng coffee

White ginseng coating solution was made by mixing white ginseng extract $\left(64^{\circ}\right.$ Brix) with HPMC solution (5 $\mathrm{g} / 100 \mathrm{~mL}$ water). Coffee beans $(100 \mathrm{~g})$ were roasted at $250^{\circ} \mathrm{C}$ for $17 \mathrm{~min}$ and then coated with $40 \mathrm{ml}$ of the white ginseng coating solution using a specially made spraying tool. After spraying, the beans were dried with cold blasts of air. The manufacturing process of ginseng coffee is shown in Fig. 1. Because spraying difficulties arose with solutions of concentrations greater than $20^{\circ}$ Brix, the maximum concentration of coating solution was set at $20^{\circ}$ Brix. Preliminary experimentation was conducted with concentrations of $5^{\circ}, 10^{\circ}, 15^{\circ}$, and $20^{\circ}$ Brix. The preliminary results showed no difference between concentrations of $10^{\circ}$ and $15^{\circ}$ Brix, but at $20^{\circ}$ Brix, ginseng taste and fragrance intensity could be perceived. Thus minimum and maximum coating concentrations of $5^{\circ}$ Brix and $20^{\circ}$ Brix, respectively, were chosen for further experimentation.

\section{Chromaticity}

The chromaticity of ginseng coffee was measured using drip coffee made from $7 \mathrm{~g}$ of crushed coffee beans and $400 \mathrm{~mL}$ of water with a coffee machine (DeLonghi, BCO 120T, USA). Chromaticity was determined by a spectrocolormeter (Color QUEST, Hunter, USA), calibrated with a standard white board ( $\mathrm{L}=92.68, \mathrm{a}=0.81, \mathrm{~b}=0.86$ ). Chromaticity was calculated as mean values using the formula $\Delta E=(\Delta L)^{2}+(\Delta a)^{2}+(\Delta b)^{2}$ after measuring lightness $(\mathrm{L})$, redness (a), and yellowness (b) (Hunter Lab Co., USA) in triplicate.

\section{Ginsenoside content}

Separation and quantitation of ginsenoside was performed with a Sep-pak separation technique following Korean Industry Standard (KS) H 2153 from the Korean Standard Information Center. This method consisted of extracting $10 \mathrm{~g}$ of coffee sample with $150 \mathrm{~mL}$ of water and mixing with a stirrer. Samples were extracted twice, and the resulting extract was filtered with Whatman No. 2 filter paper. The remaining sample after filtering was washed with $100 \%$ methanol. It was then condensed under vacuum and dissolved in $30 \%$ aqueous methanol,

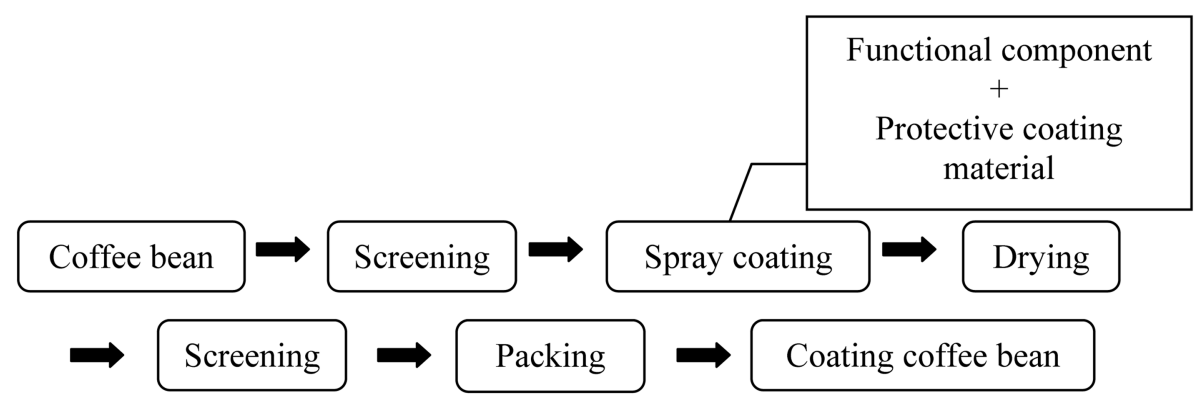

Fig. 1. Flow chart of producing the coffee beans coated with white ginseng extract. 
followed by dissolution in $25 \mathrm{~mL}$ of sample extraction solution. Next, $5 \mathrm{~mL}$ of the sample was passed through a Sep-pak $\mathrm{C}_{18}$ cartridge. The filtrate was discarded, and the Sep-pak $\mathrm{C}_{18}$ cartridge was washed with $30 \%$ aqueous methanol. Five milliliters of methanol was passed through it and filtered through a $0.45 \mu \mathrm{m}$ membrane filter, to be used as samples for analysis of saponin composition. This stage used a $\mu$ Bondapak ${ }^{\mathrm{TM}} \mathrm{C}_{18}$ Column $(10 \mu \mathrm{m}, 3.9 \times 300$ $\mathrm{mm}$, Waters, Milford, MA, U.S.A) and a Jasco UV detector $(203 \mathrm{~nm})$. A water-acetonitrile (HPLC-grade, Sigma, USA) gradient was also utilized. The acetonitrile mobile phase varied according to the following schedule: $20 \%$ (0 min), 20\% (5 min), 33\% (38 min), 80\% (63 min), 80\% (75 $\mathrm{min}$ ), 20\% (77 $\mathrm{min}$ ), and 20\% (90 $\mathrm{min})$. The mobile phase flow rate was set at $1.0 \mathrm{ml} / \mathrm{min}, 20 \mu \mathrm{L}$ of sample was injected, and sample was analyzed at $35^{\circ} \mathrm{C}$.

\section{Crude saponin content}

Approximately $5 \mathrm{~g}$ of white ginseng roast coffee powder was added to $50 \mathrm{~mL}$ n-butanol and extracted three times using a reflux cooling condenser at $80^{\circ} \mathrm{C}$. Extracted condensate was further extracted with $50 \mathrm{~mL}$ of distilled water using a separatory funnel. The resultant product of extraction was collected, and the n-butanol layer was subject to vacuum condensation, followed by the addition of $50 \mathrm{~mL}$ of ethyl ether and $30 \mathrm{~min}$ of reflux condensation at $46^{\circ} \mathrm{C}$ using a water bath. The ethyl ether was completely removed. The resulting extract was dried at $105^{\circ} \mathrm{C}$ in an oven until the weight no longer decreased.

\section{Total sugar and acidic polysaccharide content}

Two grams of sample was added to $100 \mathrm{~mL}$ of distilled water, extracted with a reflux condenser, and filtered through Whatman No. 2 filter paper. Ginseng coffee extract was filtered with a $0.45 \mu \mathrm{m}$ membrane filter and used for total sugar analysis. For acidic polysaccharide analysis, $20 \mathrm{~mL}$ of heated water extract was used and 80 $\mathrm{mL}$ of cold ethanol was added to precipitate polysaccharides. Polysaccharide particles were collected by centrifugation at $10,000 \mathrm{xg}$ for $20 \mathrm{~min}$ at $4^{\circ} \mathrm{C}$, and the precipitate was resuspended in distilled water and used for acidic polysaccharide content analysis. Total sugar content was quantified with the phenol-sulfuric acid method [18] using glucose as the standard, while acidic polysaccharide content was quantified with the carbazole-sulfuric acid method [19] using $\beta$-D-galacturonic acid as the standard.

\section{Total phenolic compound content}

Fifty milliliters of $80 \%$ aqueous methanol was added to
$2 \mathrm{~g}$ of sample and ground. Soluble components were extracted using a reflux condenser. The extract was filtered through Whatman No. 2 filter paper and condensed under vacuum, dissolved in $30 \mathrm{~mL}$ of distilled water, filtered through $0.45 \mu \mathrm{m}$ membrane filter, and used for total phenolic compound content analysis. Total phenolic compound content was quantified by the Folin-Ciocalteu method[20], and chlorogenic acid was used as the standard.

\section{Sensory evaluation}

Sensory evaluation was performed by 15 trained panelists. Coffee samples were kept at $65^{\circ} \mathrm{C}$ (an ideal temperature for tasting) and given to panelists as $50 \mathrm{~mL}$ samples. Each sample was labeled with a three-digit random number obtained from a random number table. The palatability test, color, flavor, taste, and overall palatability were scored, with a score of 9 indicating the greatest palatability. The same scoring system was used for the intensity test, which measured color, flavor, and taste and had 9 as the highest score.

\section{Statistical analysis}

The sensory evaluation results are shown as means and standard deviations calculated by SAS software (version 9.1). To verify the significance of each group, analysis of variance (ANOVA) was used for analysis, and Duncan's multiple range test was applied for a retrospective verification.

\section{RESULTS AND DISCUSSION}

\section{Chromaticity}

Table 1 shows the results from chromaticity analysis of roasted coffee beans coated with white ginseng extract. The control roasted coffee beans had an $\mathrm{L}$ value of 35.35, and the $5^{\circ}$ Brix and $20^{\circ}$ Brix white ginseng extract-coated roasted coffee beans had L values of 35.04 and 35.20, respectively. Thus the luminosity of roasted coffee beans coated with white ginseng extract decreased slightly compared to the control coffee beans. In terms of a values (degree of redness) and b values (degree of yellowness), the control coffee beans had higher values than the ginseng extract-coated coffee beans, and as the coating concentration increased, both the $\mathrm{a}$ and $\mathrm{b}$ values increased. Furthermore, for liquid coffee extractions, $\mathrm{L}$ values were 25.33 for the control and 20.67 and 34.11 for the $5^{\circ}$ Brix and $20^{\circ}$ Brix white ginseng extract-coated coffee beans, respectively. For a values were 4.39 for the control, and 18.05 and 22.37 for the $5^{\circ}$ Brix and $20^{\circ}$ Brix white gin- 
Table 1. The color of ginseng coffee treated by coating roasted coffee beans with white ginseng extract

\begin{tabular}{ccccccc}
\hline \hline $\begin{array}{c}\text { Hunter } \\
\text { color } \\
\text { value }\end{array}$ & $\begin{array}{c}\text { Control } \\
\text { (Liquid) }\end{array}$ & $\begin{array}{c}\text { WGC-1 } \\
\text { (Liquid) }\end{array}$ & $\begin{array}{c}\text { WGC-2 } \\
\text { (Liquid) }\end{array}$ & $\begin{array}{c}\text { Control } \\
\text { (Powder) }\end{array}$ & $\begin{array}{c}\text { WGC-1 } \\
\text { (Powder) }\end{array}$ & $\begin{array}{c}\text { WGC-2 } \\
\text { (Powder) }\end{array}$ \\
\hline$L^{4)}$ & $25.33 \pm 0.08^{1)}$ & $20.67 \pm 0.17$ & $34.14 \pm 0.44$ & $35.35 \pm 0.00$ & $35.04 \pm 0.18$ & $35.20 \pm 0.05$ \\
$a^{5)}$ & $4.39 \pm 0.72$ & $18.05 \pm 0.10$ & $22.37 \pm 0.62$ & $3.00 \pm 0.00$ & $2.33 \pm 0.17$ & $2.45 \pm 0.03$ \\
$b^{6)}$ & $28.66 \pm 3.17$ & $32.73 \pm 0.34$ & $51.71 \pm 0.57$ & $2.66 \pm 0.01$ & $2.10 \pm 0.24$ & $2.56 \pm 0.02$ \\
$\Delta E^{7)}$ & $78.86 \pm 0.98$ & $83.31 \pm 0.10$ & $75.70 \pm 0.19$ & $63.15 \pm 0.00$ & $63.57 \pm 0.15$ & $63.44 \pm 0.04$ \\
\hline
\end{tabular}

\footnotetext{
${ }^{1)}$ Values are the mean \pm S.D.

${ }^{2)}$ Ginseng coffee treated by coating coffee beans with $5^{\circ}$ Brix white ginseng extract.

${ }^{3)}$ Ginseng coffee treated by coating coffee beans with $20^{\circ}$ Brix white ginseng extract.

${ }^{4)}$ Luminosity.

${ }^{5)}$ Redness.

${ }^{6)}$ Yellowness.

${ }^{7)}$ Color difference.
}

seng extract-coated roasted coffee bean extracts, respectively. These results suggest a clear increase in redness directly correlated with white ginseng extract coating concentration. Moreover, b values were 28.66 for the extract from roasted control beans and 32.73 and 51.71 for extracts from roasted beans coated with $5^{\circ}$ Brix and $20^{\circ}$ Brix white ginseng extract, respectively. These results suggest that yellowness also increased directly with the concentration of white ginseng extract. Thus the color of ginseng coffee beans and extracts was affected by the concentration of white ginseng extract.

\section{Ginsenoside content}

The composition ratio of saponin in Korean ginseng is divided into protopanaxadiols (PD) and protopanaxatriols (PT). In the central nervous system, PD saponins show sedative effects, whereas PT saponins show slow sedative effect. Representative PD $\left(\mathrm{Rb}_{1}, \mathrm{Rb}_{2}, \mathrm{Rb}_{3}, \mathrm{Rc}, \mathrm{Rd}, \mathrm{Rg}_{3}\right.$, $\left.\mathrm{Rh}_{2}\right)$ and $\mathrm{PT}\left(\mathrm{Rg}_{1}, \mathrm{Re}, \mathrm{Rf}, \mathrm{Rg}_{2}, \mathrm{Rh}_{1}\right)$ saponins are $\mathrm{Rb}_{1}$ and $\mathrm{Rg}_{1}$, respectively, and the ratio of $\mathrm{PD} / \mathrm{PT}$ components is the major quality-indicating component of ginseng raw materials. Saponin analysis [21] of white ginseng and red ginseng extracts showed the PD/PT ratio to be approximately 2.01 2.44. To investigate if ginseng saponins were transferred onto roasted coffee beans after coating with white ginseng extract, ginsenoside content was determined. The results of ginsenoside content analysis are shown in Table 2. Similar PD/PT ratios of 2.67 and 2.12 were found for roasted coffee beans coated with $5^{\circ}$ Brix and $20^{\circ}$ Brix white ginseng extract, respectively. The total ginsenoside content in ginseng coffee was $0.26 \mathrm{mg} / \mathrm{g}$ in ginseng coffee coated with $5^{\circ}$ Brix white ginseng extract and $0.6 \mathrm{mg} / \mathrm{g}$ in ginseng coffee coated with $20^{\circ}$ Brix white ginseng extract. Results for main ginsenoside component
Table 2. Ginsenoside contents of ginseng coffee treated by coating roasted coffee beans with white ginseng extract

\begin{tabular}{ccc}
\hline \hline & \multicolumn{2}{c}{ Ginsenoside contents(mg/g $)^{\mathrm{I}}$} \\
\cline { 2 - 3 } & WGC-1 $^{2)}(\mathrm{mg} / \mathrm{g})$ & WGC-2 $^{3)}(\mathrm{mg} / \mathrm{g})$ \\
\hline $\mathrm{Rg}_{1}$ & 0.012 & 0.034 \\
$\mathrm{Re}$ & 0.031 & 0.087 \\
$\mathrm{Rf}$ & 0.009 & 0.026 \\
$\mathrm{Rg}_{2}+\mathrm{Rh}_{1}$ & 0.019 & 0.045 \\
$\mathrm{Rb}_{1}$ & 0.043 & 0.122 \\
$\mathrm{Rc}$ & 0.053 & 0.117 \\
$\mathrm{Rb}_{2}+\mathrm{Rb}_{3}$ & 0.043 & 0.084 \\
$\mathrm{Rd}$ & 0.047 & 0.073 \\
$\operatorname{Rg}_{3}(\mathrm{~S}, \mathrm{R})$ & 0.003 & 0.009 \\
$\mathrm{Rh}_{2}$ & 0.001 & 0.002 \\
$\mathrm{Total}_{\mathrm{saponin}}$ & 0.261 & 0.599 \\
\hline
\end{tabular}

${ }^{1)} \mathrm{PD}$ (panaxadiol saponin), $\mathrm{Rb}_{1}+\mathrm{Rb}_{2}+\mathrm{Rb}_{3}+\mathrm{Rc}+\mathrm{Rd}+\mathrm{Rg}_{3}+\mathrm{Rh}_{2}$. PT (panaxatriol saponin), $R g_{1}+R e+R f+R g_{2}+R h_{1}$.

${ }^{2)}$ Ginseng coffee treated by coating coffee beans with $5^{\circ}$ Brix white ginseng extract.

${ }^{3)}$ Ginseng coffee treated by coating coffee beans with $20^{\circ}$ Brix white ginseng extract.

showed that as the concentration of white ginseng extract coating increased, the concentration of ginsenosides $\mathrm{Rg}_{1}$, $\mathrm{Rg}_{2}, \mathrm{Rb}_{1}, \mathrm{Rb}_{2}, \mathrm{Rg}_{2}, \mathrm{Rh}_{1}$, and $\mathrm{Rg}_{3}$ increased. The standard content of $R b_{1}+R_{1}$ that indicates red ginseng products as a functional food is $0.8-34 \mathrm{mg} / \mathrm{g}$. The $\mathrm{Rb}_{1}+\mathrm{Rg}_{1}$ contents of ginseng coffee coated with $5^{\circ}$ Brix and $20^{\circ}$ Brix white ginseng extract were $0.056 \mathrm{mg} / \mathrm{g}$ and $0.156 \mathrm{mg} / \mathrm{g}$, respectively, suggesting that saponins had sufficiently transferred onto the roasted coffee beans.

\section{Crude saponin content}

The crude saponin concentrations of roasted coffee beans coated with white ginseng extract are shown in 
Table 3. Crude saponin concentrations of ginseng coffee treated by coating roasted coffee beans with white ginseng extract

\begin{tabular}{cc}
\hline \hline & Crude $\operatorname{saponin}(\%)$ \\
\hline Control(coffee bean) & 8.29 \\
WGC-1 $^{1)}$ & 8.74 \\
WGC-2 $^{2)}$ & 8.93 \\
\hline
\end{tabular}

${ }^{1)}$ Ginseng coffee treated by coating coffee beans with $5^{\circ}$ Brix white ginseng extract.

${ }^{2)}$ Ginseng coffee treated by coating coffee beans with $20^{\circ}$ Brix white ginseng extract.

Table 3. Saponin content was $8.29 \%$ for the control, $8.74 \%$ for the $5^{\circ}$ Brix white ginseng beans, and $8.93 \%$ for the $20^{\circ}$ Brix white ginseng beans. These results suggest that as the concentration of white ginseng extract increased, the crude saponin content also increased to a small degree, and that there is a high level of crude saponin content in the coffee beans themselves.

Total sugar, acidic polysaccharides, and total phenolic concentrations

Changes in total sugar and phenolic content were measured and results are shown in Table 4. For total sugar content, control coffee beans contained $4.36 \%$ sugar, $5^{\circ}$ Brix white ginseng beans contained $6.4 \%$ sugar, and $20^{\circ}$ Brix white ginseng beans contained $8.54 \%$ sugar. In terms of acidic polysaccharide content, the control coffee beans had $0.63 \%$ acidic polysaccharide content, and $5^{\circ}$ Brix and $20^{\circ}$ Brix white ginseng beans contained $0.82 \%$ and $0.84 \%$, respectively. Acidic polysaccharide contents were much lower than total sugar content in the control as well as in the white ginseng beans; the low values for treated beans might be explained by the use of white instead of red ginseng in coating the roasted coffee beans. White ginseng has very low levels of acidic polysaccharide content. The level of acidic polysaccharide content has been found to be eight times higher in red ginseng than in white ginseng due to the hydrolytic reaction of sugars in red ginseng processing [22]. In this study, total sugar and acidic polysaccharide contents increased gradually as the concentration of white ginseng extract coating increased. In terms of total phenolic content, the control coffee beans had $4.81 \%$ total phenolics, and the $5^{\circ}$ Brix and $20^{\circ}$ Brix white ginseng beans contained $5.19 \%$ and $4.92 \%$ total phenolics, respectively, suggesting that there were no large differences in total phenolic content among the samples.

\section{Sensory evaluation}

The results of the sensory evaluation of white ginseng extract-coated coffee are shown in Tables 5 and 6. As shown in Table 5, in the ginseng fragrance test there were no significant differences among scores, with the control coffee scoring 3.14 and the $5^{\circ}$ Brix and $20^{\circ}$ Brix white ginseng coffee scoring slightly higher at 3.64 and 3.93, respectively. For the coffee fragrance test results, the $5^{\circ}$

Table 4. Total sugar, acidic polysaccharide, and phenolic content of ginseng coffee treated by coating roasted coffee beans with white ginseng extract

\begin{tabular}{cccc}
\hline \hline & Total sugar (\%) & Acidic polysaccharide (\%) & Total phenolic compound (\%) \\
\hline Control(coffee bean) & $4.36 \pm 0.13^{1)}$ & $0.63 \pm 0.00$ & $4.81 \pm 0.02$ \\
WGC-1 $^{2)}$ & $6.40 \pm 0.79$ & $0.82 \pm 0.06$ & $5.19 \pm 0.03$ \\
WGC-2 $^{3)}$ & $8.54 \pm 0.62$ & $0.84 \pm 0.03$ & $4.92 \pm 0.26$ \\
\hline
\end{tabular}

${ }^{1)}$ Values are the mean \pm S.D.

${ }^{2)}$ Ginseng coffee treated by coating coffee beans with $5^{\circ}$ Brix white ginseng extract.

${ }^{3)}$ Ginseng coffee treated by coating coffee beans with $20^{\circ}$ Brix white ginseng extract.

Table 5. Consumer intensity evaluation of ginseng coffee treated by coating roasted coffee beans with white ginseng extract

\begin{tabular}{ccccc}
\hline \hline & \multicolumn{4}{c}{ Sensory characteristics } \\
\cline { 2 - 5 } & Ginseng flavor & Coffee flavor & Ginseng taste & Coffee taste \\
\hline Control(coffee bean) & $3.14^{\mathrm{a}} \pm 1.83^{1)}$ & $5.71^{\mathrm{a}} \pm 2.05$ & $3.07^{\mathrm{a}} \pm 1.86^{* * *}$ & $6.86^{\mathrm{a}} \pm 1.61^{* *}$ \\
WGC-1 ${ }^{2)}$ & $3.64^{\mathrm{a}} \pm 1.55$ & $5.14^{\mathrm{a}} \pm 1.88$ & $4.64^{\mathrm{b}} \pm 1.91^{* * *}$ & $6.07^{\mathrm{a}} \pm 1.59^{* *}$ \\
WGC-2 $^{3)}$ & $3.93^{\mathrm{a}} \pm 1.69$ & $4.79^{\mathrm{a}} \pm 2.08$ & $6.64^{\mathrm{c}} \pm 1.82^{* * *}$ & $4.64^{\mathrm{b}} \pm 1.86^{* *}$ \\
\hline
\end{tabular}

\footnotetext{
${ }^{1)}$ Values are means \pm S.D. Means with the same alphabet letter in each column are not significantly different at $p<0.05$ based on Duncan's multiple range test.

**Means with different superscripts in the same column are significantly different $(\mathrm{p}<0.005)$ by Duncan's multiple range test.

***Means with different superscripts in the same column are significantly different $(\mathrm{p}<0.0005)$ by Duncan's multiple range test.

${ }^{2)}$ Ginseng coffee treated by coating coffee beans with $5^{\circ}$ Brix white ginseng extract.

${ }^{3)}$ Ginseng coffee treated by coating coffee beans with $20^{\circ}$ Brix white ginseng extract.
} 
Table 6. Preference evaluation of ginseng coffee treated by coating roasted coffee beans with white ginseng extract

\begin{tabular}{ccccc}
\hline \hline & \multicolumn{4}{c}{ Sensory characteristics } \\
\cline { 2 - 5 } & Taste & Flavor & Color & Overall \\
\hline Control(coffee bean) & $5.57 \pm 1.80^{1)}$ & $5.86 \pm 1.75$ & $6.29 \pm 1.90$ & $5.93 \pm 1.69$ \\
WGC-1 $^{2)}$ & $5.79 \pm 1.53$ & $5.57 \pm 1.60$ & $5.93 \pm 1.73$ & $5.43 \pm 1.28$ \\
WGC-2 $^{3)}$ & $5.50 \pm 2.24$ & $5.57 \pm 1.60$ & $6.07 \pm 1.64$ & $5.44 \pm 2.31$ \\
\hline
\end{tabular}

${ }^{1)}$ Values are mean \pm S.D.

${ }^{2)}$ Ginseng coffee treated by coating coffee beans with $5^{\circ}$ Brix white ginseng extract.

${ }^{3)}$ Ginseng coffee treated by coating coffee beans with $20^{\circ}$ Brix white ginseng extract.

Brix and $20^{\circ}$ Brix white ginseng coffee scored 5.14 and 4.79 , respectively, slightly lower than the control coffee score of 5.71 but not significantly different. Results of the ginseng taste test showed that the control coffee, $5^{\circ}$ Brix white ginseng coffee, and $20^{\circ}$ Brix white ginseng coffee scored 3.07, 4.64, and 6.64, respectively, showing a significant difference in the recognition of ginseng taste in white ginseng coffee compared to the control coffee. Furthermore, the intensity of the ginseng taste increased with increasing concentrations of the white ginseng extract coating. The evaluation of the intensity of coffee taste resulted in values of 6.86 for the control and 6.07 and 4.64 for the $5^{\circ}$ Brix and $20^{\circ}$ Brix white ginseng coffee, respectively. There was no significant difference between the control coffee and the $5^{\circ}$ Brix white ginseng coffee. However, there was a significant difference between the $5^{\circ}$ Brix and $20^{\circ}$ Brix white ginseng coffee. These results suggest that there was no significant difference in recognition of ginseng taste and fragrance between the control coffee and the $5^{\circ}$ Brix white ginseng coffee, although there was a difference in ginseng taste and fragrance recognition for the $20^{\circ}$ Brix white ginseng coffee. Palatability test results are shown in Table 6 . There were no significant differences in palatability between the control coffee and the white ginseng coffee, with palatability scores of 5.57, 5.79., and 5.50 for the control coffee, $5^{\circ}$ Brix white ginseng coffee, and $20{ }^{\circ}$ Brix white ginseng coffee, respectively. No significant differences were found in comprehensive preference, with scores of 5.93 for the control and 5.43 and 5.64 for the $5^{\circ}$ Brix and $20^{\circ}$ Brix white ginseng coffee, respectively. These results suggest that when making coffee with ginseng extract-coated coffee beans, the ginseng taste and fragrance could be partially recognized depending on the coating concentration, although this did not significantly influence overall preference in choosing ginseng coffee.

\section{REFERENCES}

1. Garriques SS. Ann Chem Pharm. 90: 231 (1954)
2. Sanata S, Kondo N, Shoji J, Tanaka O, Shibata S. Studies on the saponins of ginseng. I. Structure of ginsenoside- $\mathrm{R}_{0}, \mathrm{Rb}_{1}$, $\mathrm{Rb}_{2}$, Rc and Rd. Chem Pharm Bull. 22: 421-428 (1974)

3. Yokazawa T, Kobayashi T, Oura H, KawashimaY. Studies on the mechanism of the hypoglycemic activity of ginsenoside$\mathrm{Rb}_{2}$ in streptosotocin-diabetic rats. Chem Pharm Bull. 33: 869-872 (1985)

4. Mochizuki M, Yoo YC, Matsuzawa K, Sato K, Saiki I, Tonooka S, Samukawa K, Azuma I. Inhibitory effect of tumor metastasis in mice by saponins, ginsenoside- $\mathrm{Rb}_{2}, 20(\mathrm{R})$ and 20(S)-ginsenoside- $\operatorname{Rg}_{3}$, of red ginseng. Biol Pharm Bull. 18: 1197-1202 (1995)

5. Jeong CS, Hyun JE, Kim YS. Anti-oxidative effect of ginsenoside $\mathrm{Rb}_{1}$ on the $\mathrm{HCl}$ - ethanol-induced gastric tissue in rats. Korean J Pharmacogen. 33: 252-256 (2002)

6. Jung IS, Cho YD. Effect of ginseng saponin fraction on absorption of cholesterol and serum lipid components. Korean J Ginseng Sci. 9: 232-239 (1985)

7. Yoon SH, Joo CN. Study on the preventive effect of ginsenosides against hypercholestrolemia and its mechanism. Korean J Ginseng Sci. 17: 1-12 (1993)

8. Matsuda H, Samukawa K, Kubo M. Anti-Hepatitic activity of ginsenoside Ro. Planta Med. 57: 523-526 (1991)

9. Wang BX, Cui JC, Liu AJ, Wu SK. Studies on the antifatigue effect of the saponins of stems and leaves of Panax ginseng (SSLG). J Tradit Chin Med. 3: 89-94 (1983)

10. Saito H, Yoshida Y, Tagaki K. Effects of Panax ginseng root on exhaustive exercise in mice. Jpn J Pharmacol. 24: 119126 (1974)

11. Matsuda H, Samukawa K, Kubo M. Anti-inflammatory activity of ginsenoside Ro. Planta Medica. 56: 19-23 (1990)

12. Park JD. Recent studies on the chemical constituents of Korean Ginseng (Panax ginseng C.A Meyer). Korean J Ginseng Sci. 20: 389-415 (1996)

13. Lee CR, Whang WK, Shin CG, Lee HS, Im BO, Ko SK. Comparison of gisenoside composition and contents in fresh ginseng roots cultivated in Korea, Japan and China at various ages. Korean J Food Sci Technol. 36: 847-850 (2004)

14. Nam KY. Ginseng Research Paper, Korea Ginseng and Tobacco Research Institute. p 267-270 (1990)

15. Li TSC, Wang LCH. Physioligical components and health 
effects of ginseng, Echinaceae, and sea buckthorm. Functional Foods-Biochemical and Processing Aspecs. Mazza, G.(ed.), Technomic Publishing, Lancaster, USA, p 329-356 (1998)

16. Mochizuki M, Yoo YC, Matsuzawa K, Sato K, Saiki I, TonoOka S, Samukawa KI, Azuma I. Inhibitory effect of tumor metastasis in mice by saponins, ginsenoside- $\mathrm{Rb}_{2}, 20(\mathrm{R})$-and 20(S)-ginsenoside- $\mathrm{Rg}_{3}$, of red ginseng. Biol Pharm Bull. 18: 1197-1202 (1995)

17. Park JD. Recent studies on the chemical constituents of Korean Ginseng (Panax ginseng C.A. Meyer). Korea J Ginseng Sci. 20: 389-415 (1996)

18. Dubois M, Gilles KA, Hamilton J. K, Robers PA, Smith F. Colorimetric method for determination of sugar and related substances. Anal Chem. 28: 350-356 (1956)

19. Do JH, Lee HO, Lee SK, Jang JK, Lee SD, Sung HS. Colorimetric determination of acidic polysaccharide from Panax ginseng, its extraction condition and stability. Korean J Ginseng Sci. 17: 139-144 (1993)

20. Singleton VL, Rossi JAJr. Colorimetry of total phenolic with phosphomolybdic Phosphortungstric acid reagent. American J Enology andviticulture. 16: 144-158 (1965)

21. Ko SG, Lee RC, Choi YE, Im BO, Sung JH, Yoon KR. Analysis of ginsenosides of white and red ginseng concentrates. Korean J Food Sci Technol. 35: 536-539(2003)

22. Nam KY. The comparative understanding between red ginseng and white ginseng, processed ginsengs (Panax ginseng C.A. Meyer). J Ginseng Res. 29: 1-18(2005) 